\title{
A Case Series on Severe Corrosive Injury of Upper Gastrointestinal Tract
}

\section{Sandeep Reddy J', Hari hasan $\mathrm{Ch}^{2}$, Ramya $\mathrm{V}^{2}$, Mounika $\mathrm{K}^{2}$ and Mahender $\mathrm{V}^{\star 3}$}

${ }^{1}$ Rohini Super Specialty Hospital, Hanamkonda, Warangal, Telangana State, India

${ }^{2}$ Department of Pharmacy Practice, Rohini Super specialty Hospital, and St.Peter's Institute of Pharmaceutical Sciences, Hanamkonda, Warangal, Telangana State, India

${ }^{3}$ Department of Pharmacy Practice, St.Peter's Institute of Pharmaceutical Sciences, Hanamkonda, Warangal, Telangana State, India

*Corresponding author: Mahender V, Associate Professor, Department of Pharmacy Practice, St. Peter's Institute of Pharmaceutical Sciences, Warangal, Telangana State, India 506001, E-mail: mahi.reddy125@ gmail.com

Citation: Sandeep Reddy J, Hari hasan Ch, Ramya V, Mounika K, Mahender V (2017) A Case Series on Severe Corrosive Injury of Upper Gastrointestinal Tract. J Case Rep Stud 5(1): 105. doi: 10.15744/2348-9820.5.105

Received Date: January 07, 2017 Accepted Date: February 25, 2017 Published Date: February 28, 2017

\begin{abstract}
Corrosive injuries of the Upper gastrointestinal tract (UGIT) are common in developing countries mostly mortality and morbidity is high in India due to suicidal attempts. In this case series, a 17 years old female and 51 year old male subject intentionally self-harmed by ingesting toilet cleaner containing higher amounts of hydrochloric acid and presented to the emergency department of tertiary care hospital and the different aspects of the case are discussed in detail in this paper.
\end{abstract}

Keywords: Upper Gastrointestinal Tract; Mortality; Morbidity; Toilet Cleaner

\section{Introduction}

Corrosive injuries of the Upper gastrointestinal tract (UGIT) are common in developing countries, mostly mortality and morbidity is high in India due to suicidal attempts. Both acid and alkali substances when consumed, it causes significant injury to the upper gastrointestinal tract. The extent of injury depends upon several factors such as nature of the offending agent, amount, concentration and duration of exposure [1].

Acid ingestion: Causes coagulation necrosis. In this process, hydrogen $\left(\mathrm{H}^{+}\right)$ions desiccate epithelial cells producing an eschar. This process leads to edema, erythema, mucosal sloughing, ulceration and necrosis of tissues [2].

The conventional acceptance that acids preferentially damage the stomach, due to the protective esophageal eschar, has recently been questioned, with observation of extensive esophageal damage and perforations after acid ingestion [3]. Likewise, compared with alkali, ingestion of a strong acid may be associated with a higher incidence of systemic complications, such as renal failure, liver dysfunction, disseminated intravascular coagulation and hemolysis [4].

Esophageal injury begins within minutes and may persist for hours. Initially, tissue injury is marked by eosinophilic necrosis with swelling and hemorrhagic congestion [5].

\section{Case Report}

\section{Case 1}

A 17-year-old female intentionally self-harmed by ingesting toilet cleaner containing higher amounts of hydrochloric acid and presented to the emergency department of tertiary care hospital with the complaints of hematemesis, throat pain, nausea, burning sensation. Endoscopy was done and report shows Corrosive injury of oropharynx \& UGIT severe injury of GE junction \& Stomach (Figure 1).

Treated with injection pantoprazole $40 \mathrm{mg} \mathrm{OD}$, syrup sucralfate $10 \mathrm{ml}$ on day- 1 . On day-2 C/o epigastric tenderness, nothing by mouth, pantoprazole infusion was started 80mg @ $4.0 \mathrm{ml} /$ hour. On day-3 C/o mild throat pain, dysphagia. On day-4 to day-6 observation and discharged with suitable medications. 

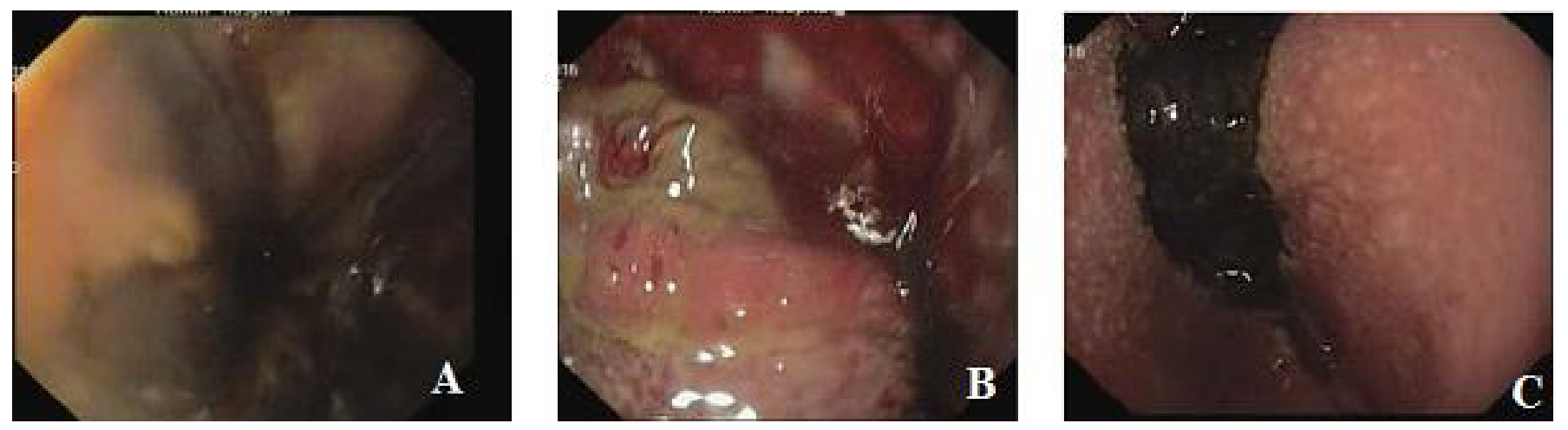

Figure 1: (A) Esophagus - Erosions \& superficial ulceration with exudates; (B) Stomach - Erosions with oozing of blood; (C) Large ulcer with black base extending into antrum

\section{Case 2}

A 51-year-oldmale intentionally self-harmed by ingesting $10 \mathrm{ml}$ toilet cleaner containing $5 \mathrm{ml}$ of hydrochloric acid and presented to the emergency department of tertiary care hospital with the complaints of hematemesis, dysphagia, throat pain, nausea, chest discomfort. Endoscopy was done and report shows Corrosive injury of larynx \& UGIT severe injury of esophagus\& Stomach (Figure 2).
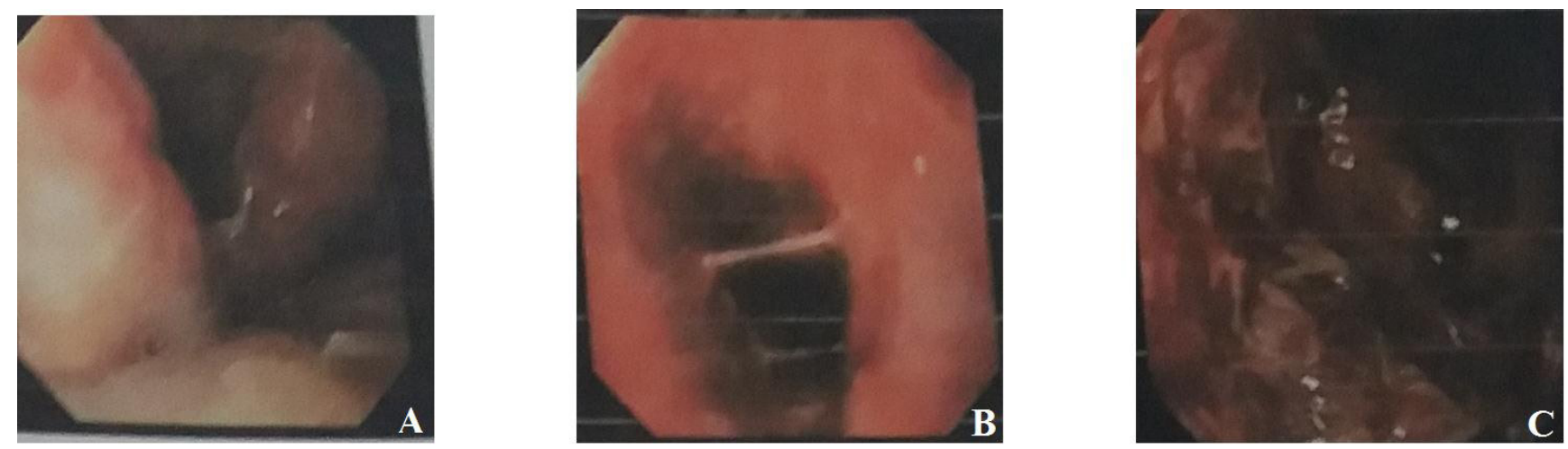

Figure 2: (A) Esophagus - Diffuse circumferential superficial ulcers \& Hemorrhages; (B and C) Stomach and Duodenum Hemorrhages with superficial ulcers and black exudates

Treated with injection pantoprazole $40 \mathrm{mg}$ OD, syrup sucralfate $10 \mathrm{ml}$, injection thiamine $1 \mathrm{~g}$ in $100 \mathrm{ml}$ normal saline, injection cefotaxime $1 \mathrm{~g}$ and nothing by mouth on day-1. On day- $2 \mathrm{C} / \mathrm{o}$ hematemesis. On day- $3 \mathrm{C} / \mathrm{o}$ hematemesis mild throat pain, dysphagia. On day-4 C/o hematemesis decreased but dysphagia. On day- 5 c/o dysphagia, aversion therapy, injection lorazepam 1cc SOS was started to stop alcohol consumption and behavior. On day- 6 to 7 observation and discharged with suitable medications.

\section{Discussion}

In some cases, several symptoms such as laryngeal edema, pulmonary edema, shock, gastrointestinal perforation, acidosis, electrolyte abnormality, or disseminated intravascular coagulation (DIC) may occur. However, specific therapies for acid ingestion do not exist, and general management by controlling breathing and circulation and treatment based on the symptoms is provided for patients [6]. The mortality rate is between $10 \%$ to $20 \%$ and rises to $78 \%$ in cases of attempted suicide [7]. Ingestion of corrosive substances either accidentally or intentionally for the purpose of suicide is a common form of poisoning in India because of easy access to acids as they are used as cheap toilet cleansers $[8,9]$.

Esophagogastroduodenoscopy is considered crucial and usually recommended in the first $12-48 \mathrm{~h}$ after caustic ingestion, though it is safe and reliable up to $96 \mathrm{~h}$ after the injury [4,10]; gentle insufflations and great caution are mandatory during the procedure. Endoscopy and even dilatation have been performed without consequences from 5 to $15 \mathrm{~d}$ after corrosive ingestion [11]. To date, the efficacy of proton-pump inhibitors and $\mathrm{H} 2$ blockers in minimizing esophageal injury by suppressing acid reflux has not been proven, though an impressive endoscopic healing after IV omeprazole infusion has been observed in a small prospective study [12].

The administration of broad-spectrum antibiotics is usually advised mainly if corticosteroids are initiated, as well as if lung involvement is identified $[13,14]$. In this case series we report two patients with different age and gender variants who are intentionally self-harmed by ingesting toilet cleaner $(10 \mathrm{ml})$ containing higher amounts of hydrochloric acid $(5 \mathrm{ml})$ due to their low socioeconomic status, diagnosed endoscopically and treated with suitable therapy. 


\section{References}

1. Lakshmi CP, Vijayhari R, Kate V, Ananthakrishnan N (2013) A hospital-based epidemiological study of corrosive alimentary injuries with particular reference to the Indian experience. Nat Med J India 26: 31-6.

2. Flomenbaum NE, Goldfrank LR, Hoffman RS, Lewin NA, Howland MA, et al. (2006) Caustics In: Goldfrank's Toxicologic Emergencies ( $8^{\text {th }}$ Edn), McGraw-Hill Education, USA.

3. Arevalo-Silva C, Eliashar R, Wohlgelernter J, Elidan J, Gross M (2006) Ingestion of caustic substances: a 15-year experience. Laryngoscope 116: 1422-6.

4. Poley JW, Steyerberg EW, Kuipers EJ, Dees J, Hartmans R, et al. (2004) Ingestion of acid and alkaline agents: outcome and prognostic value of early upper endoscopy. Gastrointest Endosc 60: 372-7.

5. Mamede RC, de Mello Filho FV (2001) Ingestion of caustic substances and its complications. Sao Paulo Med J 119: 10-5.

6. Ertekin C, Alimoglu O, Akyildiz H, Guloglu R, Taviloglu K (2004) The results of caustic ingestions. Hepatogastroenterology 51: 1397-400.

7. Lupa M, Magne J, Guarisco JL, Amedee R (2009) Update on the diagnosis and treatment of caustic ingestion. Ochsner J 9: 54-9.

8. Zargar SA, Kochhar R, Nagi B, Mehta S, Mehta SK (1992) Ingestion of strong corrosive alkalis: spectrum of injury to upper gastrointestinal tract and natural history. Am J Gastroenterol 87: 337-41.

9. Chernousov AF, Chernookov AI, Chernousov FA, Oganesian AV (2005) Treatment of a burn stricture of the oesophagus complicated with a fistula. Khirurgia 4: 4-8.

10. Previtera C, Giusti F, Guglielmi M (1990) Predictive value of visiblelesions (cheeks, lips, oropharynx) in suspected causticingestion: may endoscopy reasonably be omitted in completelynegative pediatric patients? Pediatr Emerg Care 6: 176-8.

11. Tiryaki T, Livanelioğlu Z, Atayurt H (2005) Early bougienage for relief of stricture formation following caustic esophageal burns. Pediatr Surg Int 21: 78-80.

12. Cakal B, Akbal E, Köklü S, Babalı A, Koçak E, et al. (2013) Acute therapy with intravenous omeprazole on caustic esophageal injury: a prospective case series. Dis Esophagus 26: 22-6.

13. Kay M, Wyllie R (2009) Caustic ingestions in children. Curr Opin Pediatr 21: 651-4.

14. Cheng H-T, Cheng C-L, Lin C-H, Tang J-H, Chu Y-Y, et al. (2008) Caustic ingestion in adults: the role of endoscopic classification in predicting outcome. BMC Gastroenterol 8: 31 . 